Cover. Photograph of South Fork Shenandoah River upstream of Luray Avenue. (Photograph provided by Virginia Department of Environmental Quality.) 


\section{Reconnaissance of Persistent and Emerging Contaminants in the Shenandoah and James River Basins, Virginia, During Spring of 2007}

By David Alvarez, Walter Cranor, Stephanie Perkins, Vickie Schroeder, Stephen Werner, Edward Furlong, Donald Kain, and Robert Brent

Prepared in cooperation with the Virginia Department of Environmental Quality

Open-File Report 2008-1231 


\section{U.S. Department of the Interior DIRK KEMPTHORNE, Secretary}

\section{U.S. Geological Survey \\ Mark D. Myers, Director}

\section{U.S. Geological Survey, Reston, Virginia: 2008}

For product and ordering information:

World Wide Web: http://www.usgs.gov/pubprod

Telephone: 1-888-ASK-USGS

For more information on the USGS--the Federal source for science about the Earth, its natural and living resources, natural hazards, and the environment:

World Wide Web: http://www.usgs.gov

Telephone: 1-888-ASK-USGS

Any use of trade, product, or firm names is for descriptive purposes only and does not imply endorsement by the U.S. Government.

Although this report is in the public domain, permission must be secured from the individual copyright owners to reproduce any copyrighted materials contained within this report.

Suggested citation:

Alvarez, D.A., Cranor, W.L., Perkins, S.D., Schroeder, V.L., Werner, S.L., Furlong, E.T., Kain, D., and Brent, R., 2008,

Reconnaissance of persistent and emerging contaminants in the Shenandoah and James River Basins, Virginia, during Spring of 2007: U.S. Geological Survey Open-File Report 2008-1231, 19 p. 


\section{Contents}

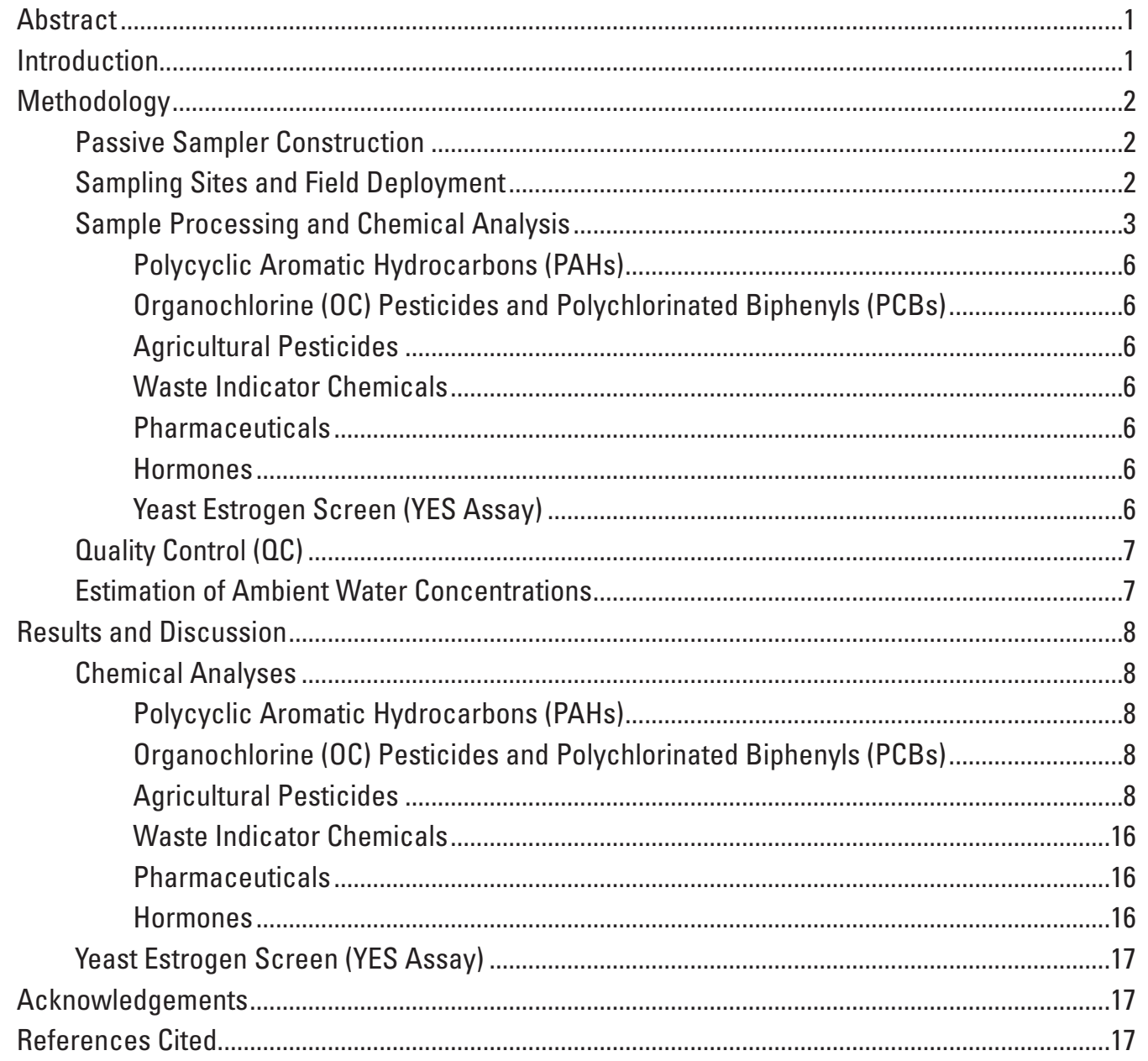

\section{Figure}

1. Map of Virginia showing the sites where passive samplers were deployed .3

\section{Tables}

1. Location of the sites in the Shenandoah and James River Basins, Virginia where passive samplers were deployed during spring of 2007.

2. Chemicals selected for analysis in the passive samplers deployed in the Shenandoah and James River Basins during spring of 2007

3. Estimated water concentrations of select polycyclic aromatic hydrocarbons (PAHs) measured by semipermeable membrane devices (SPMDs) in the Shenandoah and James River Basins, Virginia, during spring of 2007 
4. Estimated water concentrations of select organochlorine pesticides and total polychlorinated biphenyls (PCBs) measured by semipermeable membrane devices (SPMDs) in the Shenandoah and James River Basins, Virginia, during spring of 2007.

5. Estimated water concentrations and identification of select agricultural herbicides and pesticides measured by polar organic chemical integrative samplers (POCIS) in the Shenandoah and James River Basins, Virginia, during spring of 2007

6. Identification of select waste-indicator chemicals measured by polar organic chemical integrative samplers (POCIS) and semipermeable membrane devices (SPMDs) in the Shenandoah and James River Basins, Virginia, during spring of 2007.

7. Identification of select pharmaceuticals measured by polar organic chemical integrative samplers (POCIS) in the Shenandoah and James River Basins, Virginia, during spring of 2007.

8. Estimated water concentrations of select hormones measured by polar organic chemical integrative sampler (POCIS) in the Shenandoah and James River Basins, Virginia, during spring of 2007

9. Relative estrogenic potential of chemicals sampled by the polar organic chemical integrative samplers (POCIS) deployed in the Shenandoah and James River Basins, Virginia, during spring of 2007 as determined by the Yeast Estrogen Screen (YES) .15 


\section{Conversion Factors}

\begin{tabular}{|c|c|c|}
\hline Multiply & By & To obtain \\
\hline \multicolumn{3}{|c|}{ Volume } \\
\hline liter (L) & 33.82 & ounce, fluid (fl. oz) \\
\hline milliliter (mL) & 0.03382 & ounce, fluid (fl. oz) \\
\hline microliter $(\mu \mathrm{L})$ & $3.382 \times 10^{-5}$ & ounce, fluid (fl. oz) \\
\hline \multicolumn{3}{|c|}{ Length } \\
\hline centimeter $(\mathrm{cm})$ & 0.3937 & inch (in.) \\
\hline millimeter (mm) & 0.03937 & inch (in.) \\
\hline micrometer $(\mu \mathrm{m})$ & $3.937 \times 10^{-5}$ & inch (in.) \\
\hline \multicolumn{3}{|c|}{ Mass } \\
\hline $\operatorname{gram}(\mathrm{g})$ & 0.03527 & ounce (oz) \\
\hline milligram (mg) & $3.527 \times 10^{-5}$ & ounce (oz) \\
\hline microgram $(\mu g)$ & $3.527 \times 10^{-8}$ & ounce (oz) \\
\hline nanogram (ng) & $3.527 \times 10^{-11}$ & ounce (oz) \\
\hline \multicolumn{3}{|c|}{ Pressure } \\
\hline pound per square inch $\left(\mathrm{lb} / \mathrm{in}^{2}\right)$ & 6.895 & kilopascal $(\mathrm{kPa})$ \\
\hline \multicolumn{3}{|c|}{ Flow } \\
\hline cubic meters per second $\left(\mathrm{m}^{3} / \mathrm{sec}\right)$ & 0.0283 & cubic feet per second $\left(\mathrm{ft}^{3} / \mathrm{sec}\right)$ \\
\hline \multicolumn{3}{|c|}{ Concentration } \\
\hline nanogram per liter (ng/L) & $=$ & part per trillion $\left(\mathrm{ppt} ; 10^{12}\right)$ \\
\hline picogram per liter $(\mathrm{pg} / \mathrm{L})$ & $=$ & part per quadrillion (ppb; $10^{15}$ ) \\
\hline
\end{tabular}

Temperature in degrees Celsius $\left({ }^{\circ} \mathrm{C}\right)$ may be converted to degrees Fahrenheit $\left({ }^{\circ} \mathrm{F}\right)$ as follows:

$$
{ }^{\circ} \mathrm{F}=\left(1.8 \times^{\circ} \mathrm{C}\right)+32
$$

Concentrations of chemical constituents in passive samplers are given in nanogram per sampler (ng/SPMD or ng/POCIS). Estimated water concentrations of chemical constituents are given in nanogram per liter (ng/L) or picogram per liter (pg/L). 



\title{
Reconnaissance of Persistent and Emerging Contaminants in the Shenandoah and James River Basins, Virginia, During Spring of 2007
}

\author{
By David Alvarez ${ }^{1}$, Walter Cranor ${ }^{1}$, Stephanie Perkins ${ }^{1}$, Vickie Schroeder ${ }^{2}$, Stephen Werner ${ }^{3}$, Edward Furlong ${ }^{3}$, \\ Donald Kain ${ }^{4}$, and Robert Brent ${ }^{4}$
}

\section{Abstract}

Fish exhibiting external lesions, incidences of intersex, and death have recently been observed in the Shenandoah and James River Basins. These basins are characterized by widespread agriculture (intensive in some areas), several major industrial discharges, numerous sewage treatment plant discharges, and urban, transportation, and residential growth that has increased rapidly in recent years. Nine locations in the Shenandoah River Basin, Virginia, and two in the James River Basin, Virginia, were selected for study in an attempt to identify chemicals that may have contributed to the declining fish health. Two passive sampling devices, semipermeable membrane devices (SPMDs) and polar organic chemical integrative samplers (POCIS), were deployed during the spring and early summer of 2007 to measure select organic contaminants to which fish may have been exposed. This study determined that concentrations of persistent hydrophobic contaminants, such as polycyclic aromatic hydrocarbons $(<17,000$ picograms per liter), legacy pesticides $(<510$ picograms per liter), and polychlorinated biphenyls $(<1,600$ picograms per liter) were generally low and indicative of a largely agricultural area. Chlorpyrifos, endosulfan, and lindane were the most commonly detected chlorinated pesticides. Atrazine, which was detected at concentrations much greater than other pesticides associated with agricultural use, ranged from $<0.18$ to 430 nanograms per liter during the deployment period. Few chemicals characteristic of wastewater treatment plant effluent or septic tank discharges were detected. The

${ }^{1}$ U.S. Geological Survey, Columbia Environmental Research Center, 4200 New Haven Road, Columbia, Missouri 65201.

${ }^{2}$ Arctic Slope Regional Corporation (ASRC), 4200 New Haven Road, Columbia, Missouri 65201.

${ }^{3}$ U.S. Geological Survey, National Water Quality Laboratory, Denver, Colorado 80225 .

${ }^{4}$ Virginia Department of Environmental Quality, Valley Regional Office, Harrisonburg, Virginia 22801. fragrance components, galaxolide, indole, and tonalide, were the predominant waste indicator chemicals detected. Caffeine, the caffeine metabolite 1,7-dimethylxanthine, the nicotine metabolite cotinine, and the prescription pharmaceuticals carbamazepine, venlafaxine, and trimethoprim were detected at several sites. Natural and synthetic hormones were detected at a few sites with $17 \alpha$-ethynylestradiol concentrations estimated up to 8.1 nanograms per liter. Screening of the POCIS extracts for estrogenic chemicals by using the yeast estrogen screen revealed estrogenicity similar to levels reported for rural areas with minor effect from wastewater effluents.

\section{Introduction}

Anthropogenic pollution is recognized as a global problem contributing to degradation of ecosystem quality, loss of numerous plant and animal species, and potential adverse effects on human health. Sources of these environmental stressors include point and nonpoint inputs of a broad spectrum of agricultural, industrial, and residential related chemicals. Increasingly, environmental scientists are acknowledging that in addition to contaminants of historic concern, emerging contaminants, including pharmaceuticals, new generation pesticides, personal care products, and natural and synthetic hormones, are potential sources of adverse effects.

Fish kills have been increasing in regularity in the Shenandoah River and Potomac River Basins in Virginia (Blazer and others, 2007). These observations were made primarily during the spring, and mostly in smallmouth bass (Micropterus dolomieu), red-breast sunfish (Lepomis auritus), and various species of suckers. The cause(s) of these phenomena are unknown; however, the input of anthropogenic organic chemicals into the basin may be a factor. A sampling approach that provides a time weighted average assessment is critical in understanding the consequences of exposure to these diverse mixtures of chemicals. The SPMD and the POCIS are two commonly used passive sampling technologies that provide a 
means of integratively sampling a wide array of bioavailable waterborne nonpolar and polar organic contaminants.

Passive samplers are deployed for weeks to months, extract chemicals continuously from the water, and sample only dissolved chemicals, excluding chemicals associated with particulate, suspended sediment, or colloidal matter. During a typical one-month exposure, a passive sampler potentially can sample tens to hundreds of liters (L) of water, allowing for the detection of chemicals at low concentrations, or those that are present episodically. This time integration of contaminants is not readily achievable using standard sampling methods that collect discrete 1- or 2-L water samples.

The SPMD consists of a layflat low-density polyethylene membrane tube containing a neutral lipid (triolein). The SPMD is designed to mimic key aspects of the bioconcentration process that results in elevated contaminant concentrations in organism tissues after exposure to trace hydrophobic organic contaminants in aquatic environments (Huckins and others, 2006). Sampling of compounds with moderate to high (greater than 3) octanol to water partition coefficients $\left(K_{\text {ow }} \mathrm{s}\right)$ is integrative, meaning extracted residues are constantly accumulated without significant losses back into the environment. As such, chemcial concentrations are reported as time weighted average values. Like SPMDs, the POCIS is designed to mimic key aspects of the bioconcentration process and exposure of an organism to hydrophilic organic contaminants. The POCIS consists of a solid phase sorbent or mixture of sorbents contained between two sheets of a microporous polyethersulfone membrane (Alvarez and others, 2004, 2007). Sampling of compounds with low to moderate (less than 3 ) $K_{\text {ow }}$ s is integrative and chemical concentrations are reported as time weighted average values.

The U.S. Geological Survey (USGS) in cooperation with the Virginia Department of Environmental Quality (VADEQ), conducted this study to identify anthropogenic organic chemicals and assess the estrogenicity of the complex mixtures of chemicals by using an in vitro assay. Passive samplers were used to detect potentially endocrine disrupting compounds and other chemicals at 10 locations on various rivers and streams within the Shenandoah and James River Basins. SPMDs and POCIS were deployed between March and May 2007 to address the potential effect of agricultural and municipal inputs into the basin during the months when fish kills have been most prevalent. A suite of anthropogenic organic contaminants was selected for study, including polycyclic aromatic hydrocarbons (PAHs), legacy organochlorine pesticides (OCs), polychlorinated biphenyls (total $\mathrm{PCBs}$ ), select natural and synthetic hormones, current-use agricultural pesticides, pharmaceuticals, and waste indicator contaminants.

\section{Methodology}

\section{Passive Sampler Construction}

The passive samplers used in this study were purchased from Environmental Sampling Technologies (EST Labs, St. Joseph, Missouri). For each site, six POCIS and three SPMDs were used. The POCIS used in this study contained Oasis HLB as the chemical sequestration medium enclosed between two polyethersulfone membranes. Oasis HLB is a functionalized polystyrene-divinylbenzene polymer with blended hydrophilic-lipophilic properties, commonly used in environmental monitoring studies for a range of organic contaminants (Kolpin and others, 2002; Cahill and others, 2004; Tran and others, 2007). Each POCIS unit had an effective sampling surface area of 41 square centimeters and a membrane surface area to sorbent mass ratio of 180 square centimeters per gram conforming to the specification of a standard POCIS (Alvarez and others, 2004).

Each SPMD consisted of a 97 centimeter $(\mathrm{cm})$ long ( $86 \mathrm{~cm}$ between the lipid-containment seals) by $2.5 \mathrm{~cm}$ wide layflat low-density polyethylene tubing containing 1.0 milliliter $(\mathrm{mL})$ of purified triolein (Lebo and others, 2004). The membrane surface area to total SPMD volume ratio of SPMDs used in this study was 86 square centimeters per $\mathrm{mL}\left(\mathrm{cm}^{2} / \mathrm{mL}\right)$, and triolein represented 20 percent of the mass of the SPMDs conforming to a "standard SPMD" as defined by Huckins and others (2006). Two of the three SPMDs used at each site were fortified with about 21 to 24 nanograms (ng) of each of the three PCB congeners 14, 29, and 50 which were selected as performance reference compounds (PRCs). A description of the PRC approach is given in the Estimation of Ambient Water Concentrations section. In addition to the field deployed SPMDs, two freshly prepared SPMDs were fortified with the PRC mixture and were used as a measure of the initial concentration for the PRC modeling.

\section{Sampling Sites and Field Deployment}

Eleven sites were selected by members of VADEQ. These sites included eight fish kill sites in the Shenandoah River Basin, one "control" site in the Shenandoah River Basin, and two "control" sites in the James River Basin. The control sites were streams with similar characteristics, including fish communities, which had not experienced fish kills in previous years. However, during the 2007 passive sampler sampling, a few dead fish were found at the Cedar Creek control site and a substantial fish kill was observed at the Cowpasture 


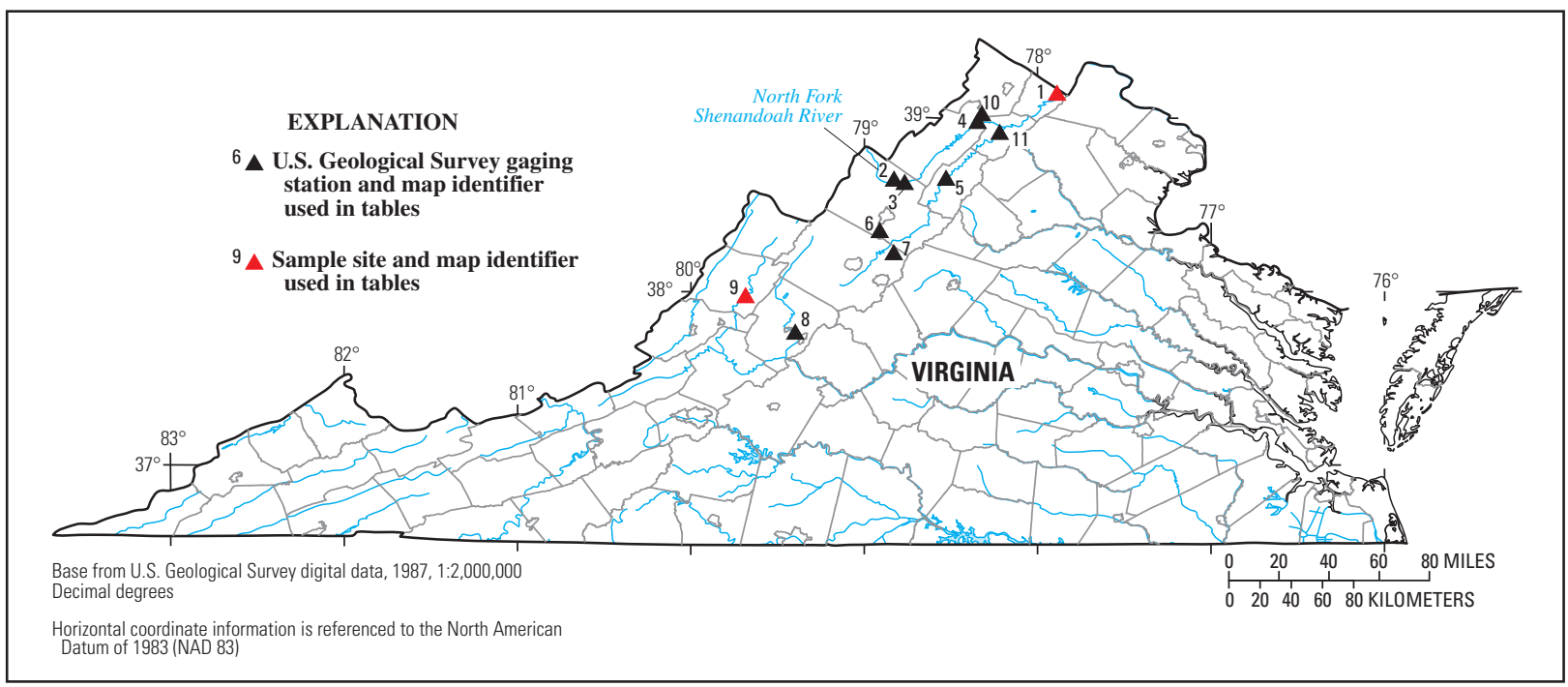

Figure 1. Sites in Virginia where passive samplers were deployed. Locations identified by numbers on the map correspond to the following sampling sites: 1, Shenandoah mainstem at Berryville; 2, North Fork Shenandoah River-Cootes Store; 3, North Fork Shenandoah River-Linville Creek at Broadway WWTP; 4, North Fork Shenandoah River-Strasburg Route 55 bridge; 5, South Fork Shenandoah River-White House (Luray) at Route 211; 6, South Fork Shenandoah River-North River at Port Republic Bridge; 7, South Fork Shenandoah River-South River at Harriston; 8, Maury River; 9, Cowpasture River; 10, Cedar Creek StalhInaker Property; 11, South Fork Shenandoah River-Front Royal.

River control site. At each site, custom protective deployment cages were used to contain three SPMDs and six POCIS in the water for periods of 42 to 49 days between March and May 2007. The samplers from South Fork Shenandoah River at Front Royal, Virginia (USGS stream-gaging station \#1631000) was found on the river bank, the apparent result of vandalism and could not be used. At the remaining 10 sites, the samplers were found intact and submerged in the water. During retrieval from the field, the SPMDs were removed from the deployment cages and placed in clean, metal cans and returned to the laboratory in coolers on ice where the SPMDs were inspected and stored at less than -20 degress Celsius $\left({ }^{\circ} \mathrm{C}\right)$ until processing and analysis. The POCIS were removed from the deployment cages, wrapped in clean aluminum foil and sealed in zipper-type plastic bags. The plastic bags were stacked in a cooler with ice and returned to the laboratory where the POCIS were inspected and stored as described for the SPMDs.

\section{Sample Processing and Chemical Analysis}

Each SPMD and POCIS was extracted individually before designating extracts for specific processing and analysis procedures. SPMDs were processed and analyzed for PAHs, OC pesticides, total PCBs, and waste indicator chemicals (table 2). Agricultural pesticides, hormones, pharmaceuticals, and select waste indicator contaminants were measured in the POCIS (table 2). Some chemicals are measured in multiple analysis methods and, therefore, the generic chemical group name given for a method may not be fully descriptive of all chemicals analyzed in that method. For example, atrazine is included in both the agricultural pesticides method and the waste indicator chemicals method. Even though atrazine would not be considered a typical contaminant expected in treated wastewater effluent, atrazine has been found in watersheds receiving wastewater effluent in rural areas where atrazine is applied to fields (Alvarez and others, 2008). POCIS extracts also were screened by using the yeast estrogen screen (YES assay) to test for the total estrogenicity of sampled chemicals (Alvarez and others, 2008a, 2008b; Rastall and others, 2004).

The procedures used for preparing SPMD samples for analysis were similar to previously published approaches (Alvarez and others, 2008b; Petty and others, 2000). The target chemicals were recovered from the SPMDs by dialysis with hexane, filtration through 0.45 micrometer $(\mu \mathrm{m})$ filter cartridges, isolation of the target chemicals by size exclusion chromatography (SEC), followed by class-specific cleanup and analysis. One of the PRC-SPMDs from each site was used for the analysis of PAHs; the other was used for OC pesticides and total PCB measurements. The remaining SPMD from each site, which did not contain PRCs, was analyzed for the waste indicator chemicals.

Published procedures were used for preparing the POCIS samples for analysis in this study (Alvarez and others, 2004, 2007, 2008b). Chemicals of interest were recovered from the POCIS sorbent by using $40 \mathrm{~mL}$ of methanol, with the exception of two POCIS from each site that were designated for waste indicator chemical analysis. These two POCIS were extracted by using $25 \mathrm{~mL}$ of an 80:20 volume-to-volume ratio (v:v) dichloromethane:methyl-tert-butyl ether solution. The liquid volume of each extract was reduced by rotary 


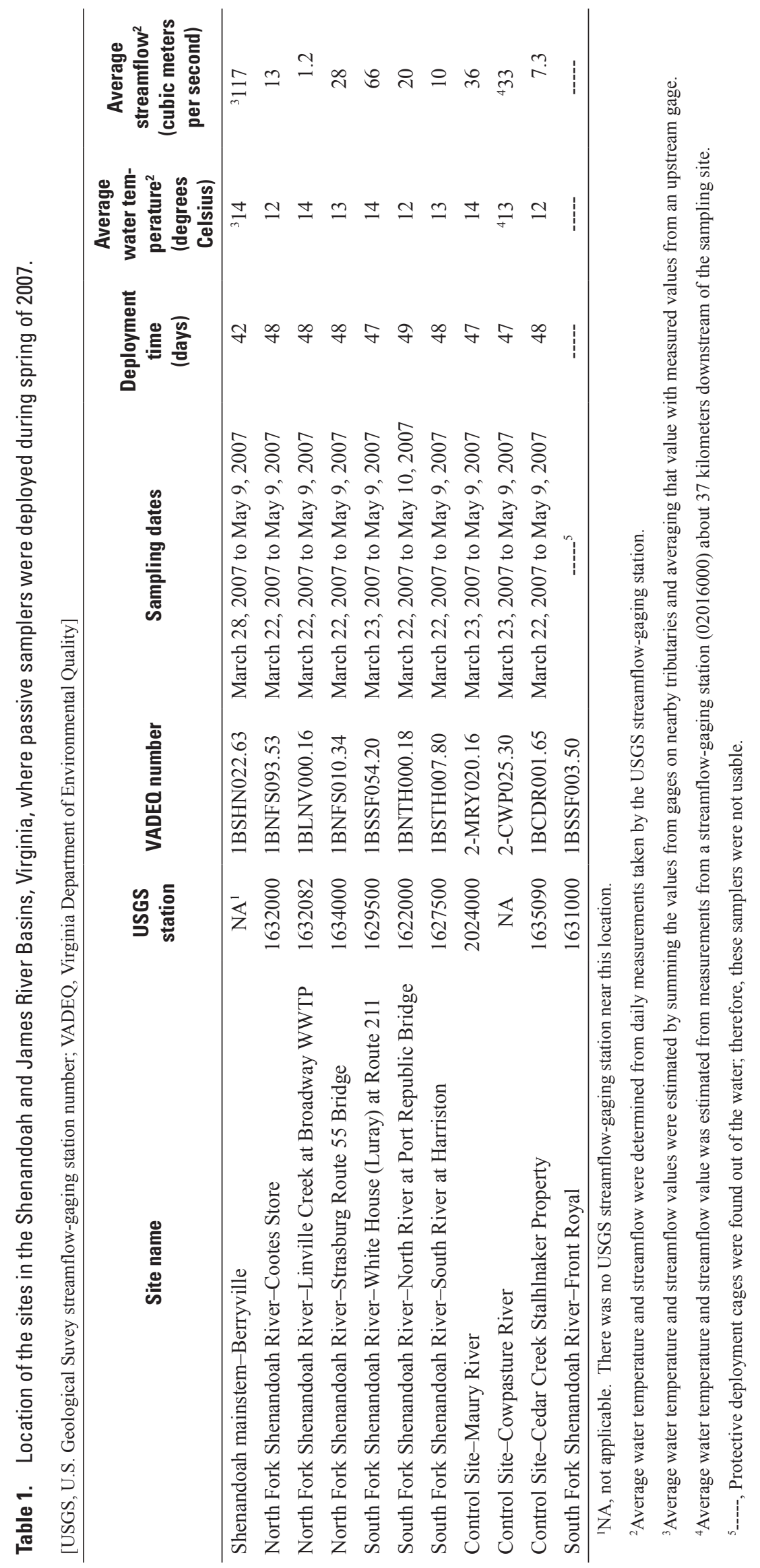




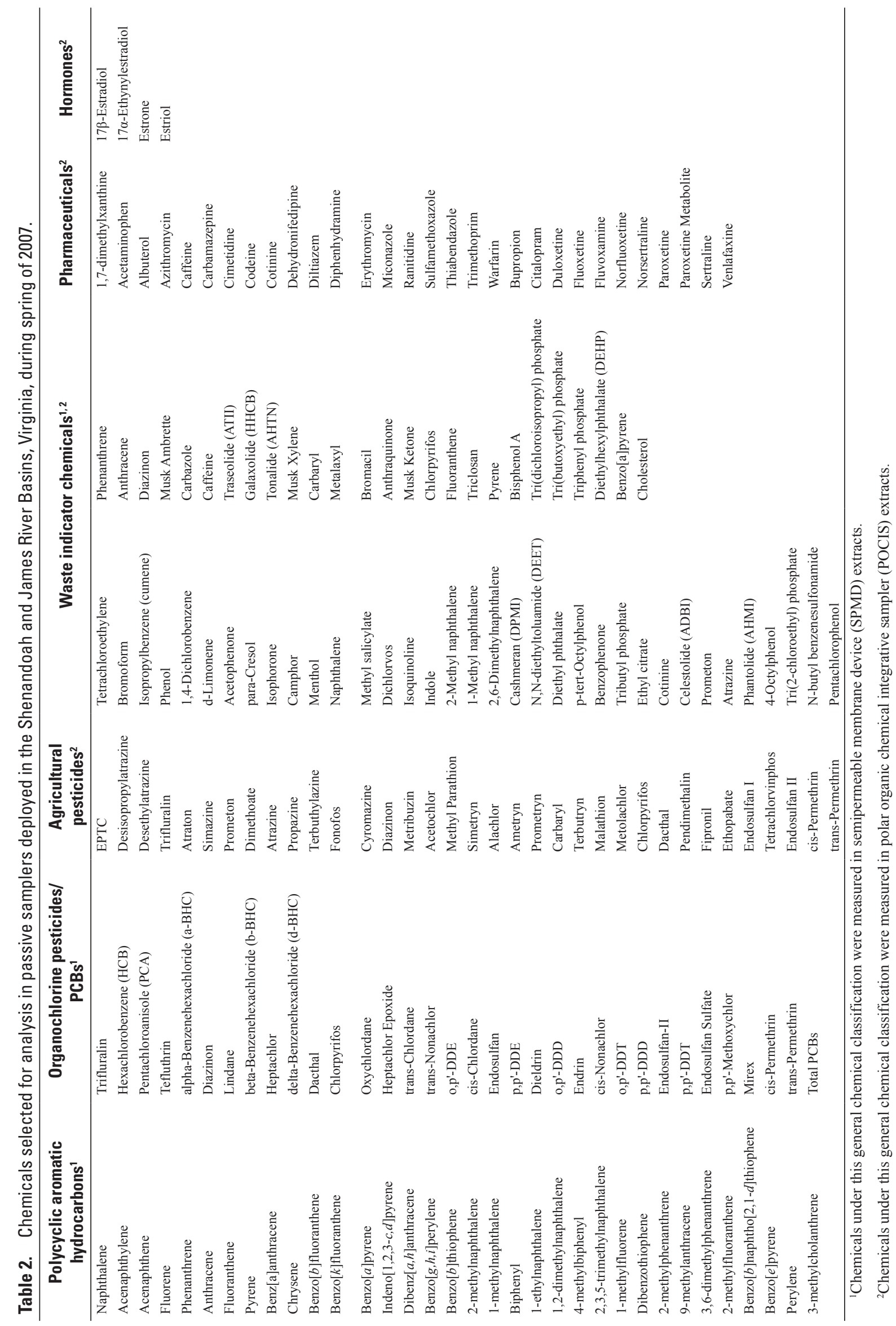


evaporation and filtered through 0.45 micrometer $(\mu \mathrm{m})$ filter cartridges. From each site, the extracts from the two waste indicator POCIS were composited into a 2-POCIS equivalent sample, thereby, increasing the amount of chemical in each sample to aid in detection. The remaining four POCIS extracts from each deployment canister were kept as individual samples designated for processing for agricultural pesticides, hormones, pharmaceuticals, and the YES assay.

Between one and four of the original six POCIS deployed at each site were received at the laboratory damaged and could not be used. In these cases, the extracts from the remaining intact POCIS were split to best accommodate the needs of the planned chemical analyses. This practice may have had the unfortunate result that some chemicals that may have been in the extract at a concentration near the method detection limit may not have been detected. None of the SPMDs were damaged.

\section{Polycyclic Aromatic Hydrocarbons (PAHs)}

Following SEC, samples designated for PAHs were processed by using a tri-adsorbent column consisting of phosphoric acid silica gel, potassium hydroxide impregnated silica gel, and silica gel (Petty and others, 2000). The gas chromatographic (GC) analyses for selected PAHs were conducted by using a GC system with a mass selective detector (GC/MSD) as described by Alvarez and others (2008b).

\section{Organochlorine (OC) Pesticides and Polychlorinated Biphenyls (PCBs)}

The OC/PCB SPMD samples were further enriched after SEC by using a Florisil column followed by fractionation on silica gel (Petty and others, 2000). The first silica gel fraction (SG1) contained greater than 95 percent of the total PCBs, hexachlorobenzene, heptachlor, mirex and 40 to 80 percent of the p,p'-DDE when present in the extracts. The second fraction (SG2) contained the remaining 28 target OC pesticides and less than 5 percent of the total PCBs (largely, mono- and dichlorobiphenyl congeners). SPMD samples were analyzed for PCBs and OCs by using a GC equipped with an electron capture detector (ECD). Instrumental conditions for the $\mathrm{OC} / \mathrm{PCB}$ analyses have been previously reported (Alvarez and others, 2008b).

\section{Agricultural Pesticides}

Details for the processing and analysis of POCIS for agricultural pesticides have been reported previously (Alvarez and others, 2008b). The extracts were fractionated using SEC, followed by sample cleanup and enrichment by Florisil adsorption chromatography. Analysis was performed using a GC/MSD as described by Alvarez and others (2008b).

\section{Waste Indicator Chemicals}

Analysis of waste indicator chemicals was initially performed on raw SPMD and POCIS extracts because of the difficulty in adequately "cleaning up" a sample while maintaining the integrity of such a diverse set of chemicals. Because of matrix specific interferences, such as residual lipid, the analysis of the SPMDs resulted in inconclusive data that required additional processing of the SPMD samples by using SEC prior to reanalysis. Analyses were performed on the GC/MSD system previously described by Alvarez and others (2008b). Identification of the targeted chemicals was performed by using full-scan mass spectrometry, and quantification was performed by selecting ions unique to each chemical.

\section{Pharmaceuticals}

Extracts for pharmaceutical analysis were solvent exchanged into acetonitrile and sealed in amber glass ampules before being shipped to the USGS National Water Quality Laboratory in Denver, Colorado, for analysis by using liquid chromatography/tandem mass spectrometry (LC/MS/MS). Two analyses of the POCIS extracts were performed: one for a suite of commonly used prescription and over-the-counter pharmaceuticals, and a second for current use antidepressants. Instrumental parameters for these analyses have been previously described (Alvarez and others, 2008a; Cahill and others, 2004; Schultz and Furlong, 2008).

\section{Hormones}

Four common hormones were selected in this study. These hormones included the synthetic hormone 17 $\alpha-$ ethynylestradiol used in oral contraceptives, the natural hormone 17 $\beta$-estradiol, and two metabolites, estrone and estriol. Extracts selected for hormone analysis required derivatization of the hormones to facilitate analysis by using a GC/MSD. Derivatization of extracts, quality control (QC) samples, and calibration standards for GC/MSD analysis were performed as described by Alvarez and others (2008a).

\section{Yeast Estrogen Screen (YES Assay)}

The YES assay uses recombinant yeast cells transfected with the human estrogen receptor. Upon binding these cells to an estrogen or estrogen-mimic, a cascade of biochemical reactions results in a color change that can be measured spectrophotometrically (Routledge and Sumpter, 1996; Rastall and others, 2004). SPMDs and POCIS extracts from each site were screened for total estrogenicity in conjunction with a series of negative (solvent) and positive (17 $\beta$-estradiol) controls (Alvarez and others, 2008b; Rastall and others, 2004). Estradiol equivalent factors (EEQ) for the samples were determined to provide a relative measure of estrogenicity. The EEQ is an estimate of the amount of $17 \beta$-estradiol, a natural 
hormone, that would be required to give a response equivalent to that of the complex mixture of chemicals sampled at each site.

\section{Quality Control (OC)}

A rigorous QC plan was employed to ensure the reliability of the data obtained. The QC samples for the SPMDs and POCIS consisted of laboratory controls such as reagent blanks, matrix blanks, surrogate recovery, and fortified matrix recovery checks were included in the processing of the study samples. Instrument verification checks, reference standards, and positive and negative controls for the YES assay were used. Detailed discussions on the benefits of each type of control sample have been reported by Alvarez and others (2007) and Huckins and others (2006).

Radiolabeled surrogates of model compounds were used to allow for a rapid determination of results. Proper operation of the SEC system was verified by the recovery of ${ }^{14} \mathrm{C}$ phenanthrene (a common PAH) solvent spikes that averaged 96 percent with 2.0 percent relative standard deviation $(n=5)$. A freshly prepared SPMD was fortified with ${ }^{14} \mathrm{C}$ phenanthrene and processed concurrently with the remainder of the study SPMDs. The measured recovery of the ${ }^{14} \mathrm{C}$ phenanthrene of 92 percent following dialysis and SEC indicated acceptable performance of the method. Select POCIS were spiked with ${ }^{3} \mathrm{H} 17 \alpha$-ethynylestradiol (a widely used synthetic hormone) and ${ }^{14} \mathrm{C}$ diazinon (a common organophosphate insecticide) resulting in mean recoveries of 98 percent (1.4 percent relative standard deviation, $\mathrm{n}=2$ ) and 86 percent ( 3.4 percent relative standard deviation, $\mathrm{n}=5$ ), respectively.

No matrix (fabrication and field) blanks for the passive samplers supplied by the commercial vendor were included with the deployed samplers for processing and analysis. The lack of these blanks makes it difficult to determine whether part or all of the measured chemicals in the deployed samplers were sampled from the water or because of airborne contamination or from handling of the samplers during construction, deployment, retrieval, and shipping. Laboratory matrix (SPMD and POCIS) blanks were created immediately prior to the initiation of each processing set and were processed concurrently with the field deployed samplers. Overall, the blanks indicated no sample contamination related to the processing and handling of the samplers in the laboratory. On the basis of past studies, field blanks, if used, likely would not have shown a substantial background contamination (Alvarez and others, 2008a; 2008b; Petty and others, 2000).

Method detection (MDL) and method quantification (MQL) limits were estimated from low-level calibration standards as determined by the signal-to-noise ratio of the response from the instrumental analysis (Keith, 1991). The MDLs were determined as the mean plus three standard deviations of the response of a coincident peak during instrumental analysis. The MQLs were determined as the greater of either the coincident peak mean plus 10 standard deviations, or the concentration of the lowest-level calibration standard. In cases of no coincident peak, the MQL was set at the lowestlevel calibration standard and the MDL was estimated to be 20 percent of the MQL. For reporting purposes, the MDLs and MQLs for each sample set were determined as ambient water concentrations on the basis of the average PRC data across the sites for each sampling period. When sampling rate information was not available, the MDLs and MQLs were expressed as the mass of chemical sequestered by a single sampler (ng/POCIS or ng/SPMD).

\section{Estimation of Ambient Water Concentrations}

SPMD and POCIS uptake kinetics (sampling rates) are required to estimate aquatic concentrations of environmental contaminants. By using developed models (Alvarez and others, 2004, 2007; Huckins and others, 2006) along with data from the analysis of the PRC concentrations and sampling rates (when available), the bioavailable aqueous concentrations of analytes detected in POCIS and SPMDs can be estimated.

The effects of exposure conditions on the chemical uptake and dissipation rates into passive samplers are largely a function of exposure medium temperature; facial velocity/ turbulence at the membrane surface, which in turn is affected by the design of the deployment apparatus (baffling of media flow-turbulence); and membrane biofouling. PRCs analytically are non interfering organic compounds with moderate to high fugacity from SPMDs that are added to the lipid before membrane enclosure and field deployment (Huckins and others, 2006). By comparing the rate of PRC loss during field exposures to that of laboratory studies, an exposure adjustment factor (EAF) can be derived and used to adjust sampling rates to more accurately reflect the site-specific sampling rates. A mixture of PRCs often is used to ensure at least one will have the optimal 20-80 percent loss (Huckins and others, 2006). PRCs will undergo increased loss as their $\log K_{\text {ow }}$ value decreases. The amount of loss will be dependent on the same environmental factors that affect chemical uptake. Because of the strong sorptive properties of the adsorbents used in the POCIS, attempts to incorporate PRCs into the POCIS have failed (Alvarez and others, 2007).

Uptake of hydrophobic chemicals into SPMDs follows linear, curvilinear, and equilibrium phases of sampling. Integrative (or linear) sampling is the predominant phase for compounds with $\log K_{\mathrm{ow}}$ values $\geq 5.0$ and exposure periods of up to one month. During the linear uptake phase the ambient chemical concentration $\left(C_{\mathrm{w}}\right)$ is determined by

$$
C_{\mathrm{w}}=N / R_{\mathrm{s}} \mathrm{t}
$$

where $N$ is the amount of the chemical sampled by an SPMD (typically $\mathrm{ng}$ ), $R_{\mathrm{s}}$ is the SPMD sampling rate (L/d), and $\mathrm{t}$ is the exposure time (d). Estimation of a site specific $R_{\mathrm{s}}$ of a chemical in an SPMD is the calculated EAF from the PRC data 
multiplied by the $R_{\mathrm{s}}$ measured during laboratory calibration studies (Huckins and others, 2006). A key feature of the EAF is that it is relatively constant for all chemicals that have the same rate-limiting barrier to uptake, allowing PRC data to be applied to a range of chemicals.

Uptake of hydrophilic organic chemicals by the POCIS is controlled by many of the same rate-limiting barriers allowing the use of the same models to determine ambient water concentrations. Previous data indicate that many chemicals of interest remain in the linear phase of sampling for at least 56 days (Alvarez and others, 2004, 2007); therefore, the use of a linear uptake model (eq. 1) for the calculation of ambient water concentrations was justified.

\section{Results and Discussion}

\section{Chemical Analyses}

The data presented in tables $3-9$ are reported as estimated water concentrations, when possible. In cases where the sampling rate for a chemical was not known, the data were flagged as not calculated (NC), and the result was given as mass of chemical in the passive sampler. Although the mass of chemical per sampler data is more qualitative, the data are still useful in identifying chemicals present at a site and comparing the relative amounts of a chemical between sites. Data that were less than the MDL were given as a less than $(<)$ value based on the estimated water concentration of the detection limit during those site conditions (deployment time, flow, temperature, and biofouling) or as the mass of chemical per sampler. Data that are greater than the MDL, but less than the MQL, are shown in italics. Any data less than the MQL have a large degree of statistical uncertainty and are presented for informational purposes only. All reportable data greater than the MQL are shown in bold type.

\section{Polycyclic Aromatic Hydrocarbons (PAHs)}

PAHs (table 3) detected in the study were generally at low concentrations indicative of a rural setting with minimal urbanization or industrial effect. The primary PAHs detected included fluoranthene, pyrene, phenanthrene, naphthalene, and the substituted naphthalenes that are common in environmental samples. The two sites with the greatest number of PAHs detected were the Cootes Store and Strasburg sites on the North Fork of the Shenandoah River with 13 and 11 of the 16 priority pollutant PAHs detected. Naphthalene was detected at all sites with the greatest concentrations of 12,000 to 17,000 picograms per liter $(\mathrm{pg} / \mathrm{L})$ found at the three control sites. However, these concentrations are substantially below the reported long-term no effect level of 0.45 milligram per liter $(\mathrm{mg} / \mathrm{L})$ for fathead minnow and rainbow trout (DeGraeve and others, 1982). The Maury River control site also contained elevated concentrations of PAHs that were greater than many of the other study sites.

\section{Organochlorine (OC) Pesticides and Polychlorinated Biphenyls (PCBs)}

Several OC pesticides were detected at reportable concentrations greater than the MQL (table 4). Lindane, chlorpyrifos, and endosulfan were detected most often and at the greatest concentrations. Lindane, an OC insecticide banned for agricultural use in 2006 but still approved for treatment of lice, was at quantifiable concentrations at five sites with a maximum concentration of $240 \mathrm{pg} / \mathrm{L}$ at the South Fork Shenandoah River at Route 211 site. Lindane has been shown to cause anemia, inhibiton of ATPase activity and alterations in nervous function in fish (Joy, 1982; Hanke and others, 1983; Gonzalez and others, 1987). Chlorpyrifos (also known as Dursban or Lorsban) is an organophosphate insecticide widely used until banned in 2000 for residential use; however, chlorpyrifos is still used for agricultural purposes. Carr and others (1997) reported up to 97 percent inhibition of acetylcholinesterase in the brains and skeletal muscles of bass, bluegill, and shiners resulting from exposure of chlorpyrifos runoff from an adjacent construction site. Chlorpyrifos was found at 9 of 10 sites with a maximum concentration of $300 \mathrm{pg} / \mathrm{L}$ at the North Fork Shenandoah River-Linville Creek at Broadway wastewater treatment plant (WWTP) site. Endosulfan is a neurotoxic OC insecticide banned in many countries but widely used in agriculture in the United States. Exposure of various fish species to sublethal doses of endosulfan resulted in the onset of lesions on livers and brains and reduction in enzyme activity (Matthiessen and Roberts, 1982; Tripathi and Verma, 2004). Endosulfan was detected at all sites with a maximum concentration of $270 \mathrm{pg} / \mathrm{L}$ at the Cedar Creek control site. Both chlorpyrifos and endosulfan are listed by the USEPA as suspected endocrine disruptors. Many of the persistent legacy pesticides such as cis- and trans-chlordane, cis- and trans-nonachlor, and DDT complex were detected at low concentrations up to $64 \mathrm{pg} / \mathrm{L}$ ( $p, p^{\prime}$-DDE at North Fork Shenandoah River at Strasburg). The detection of these pesticides was not surprising because of the nearly ubiquitous global distribution from years of excessive use before being banned. PCBs were detected at concentrations greater than the MQL at the Shenandoah River mainstem at Berryville $(740 \mathrm{pg} / \mathrm{L})$, North Fork Shenandoah River at Strasburg $(1,600 \mathrm{pg} / \mathrm{L})$ and South Fork Shenandoah River at Route 211 $(560 \mathrm{pg} / \mathrm{L})$.

\section{Agricultural Pesticides}

Atrazine, simazine, and metolachlor were the most commonly detected herbicides in this study. Atrazine concentrations ranged from below detection $(<0.18 \mathrm{ng} / \mathrm{L})$ to 430 nanograms per liter $(\mathrm{ng} / \mathrm{L})$. The atrazine metabolite desethylatrazine was detected at several sites. Atrazine and 


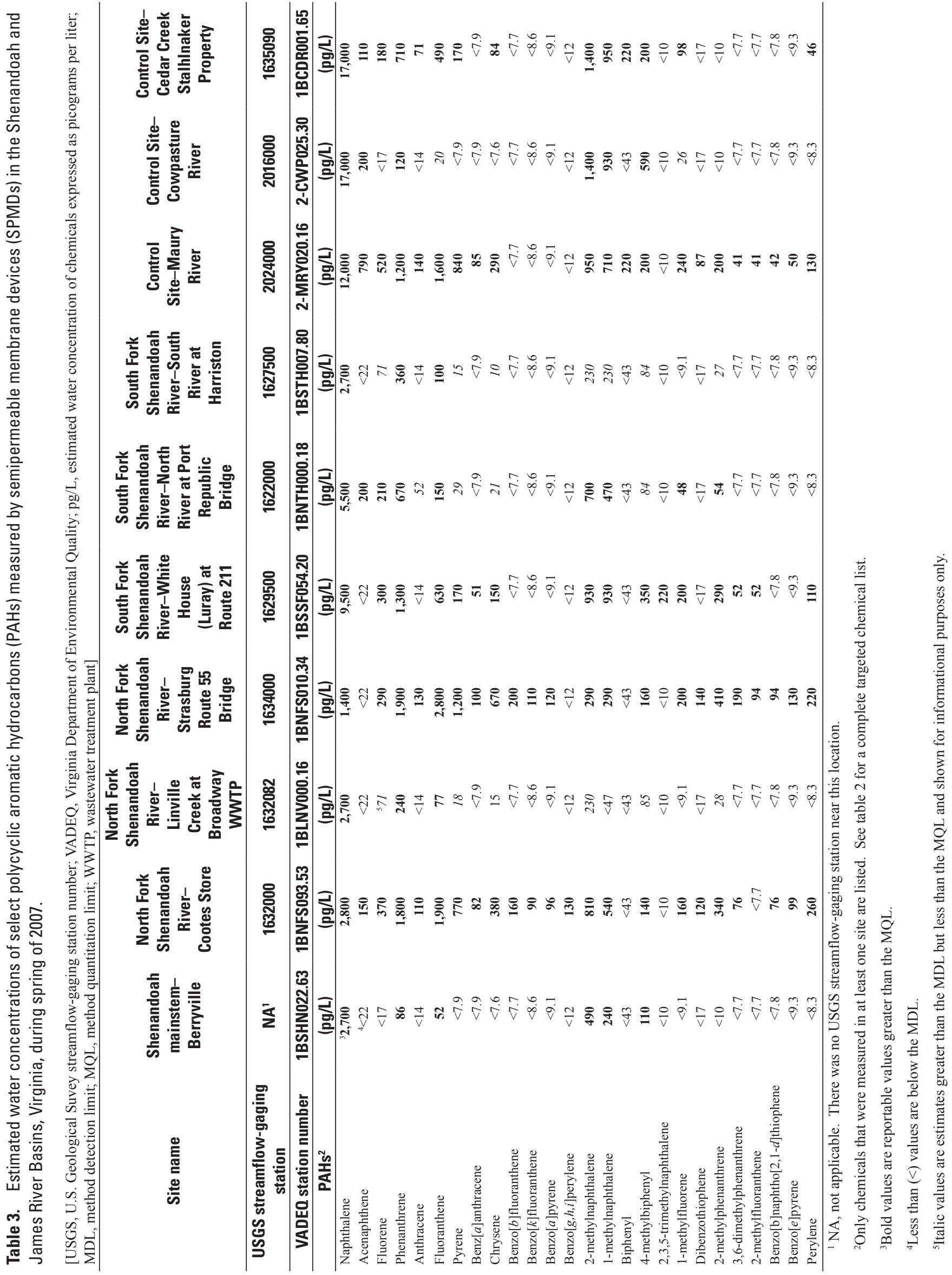




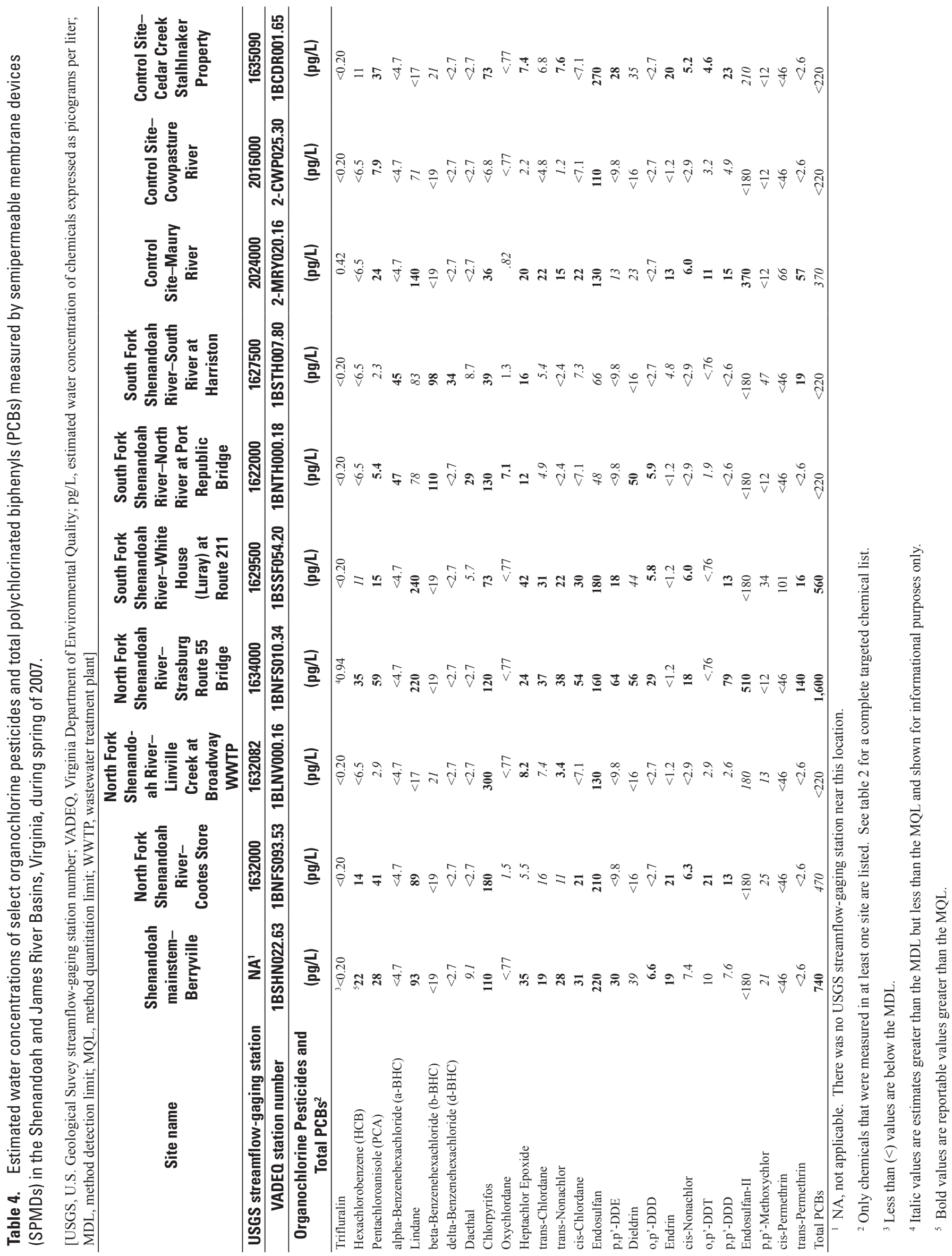




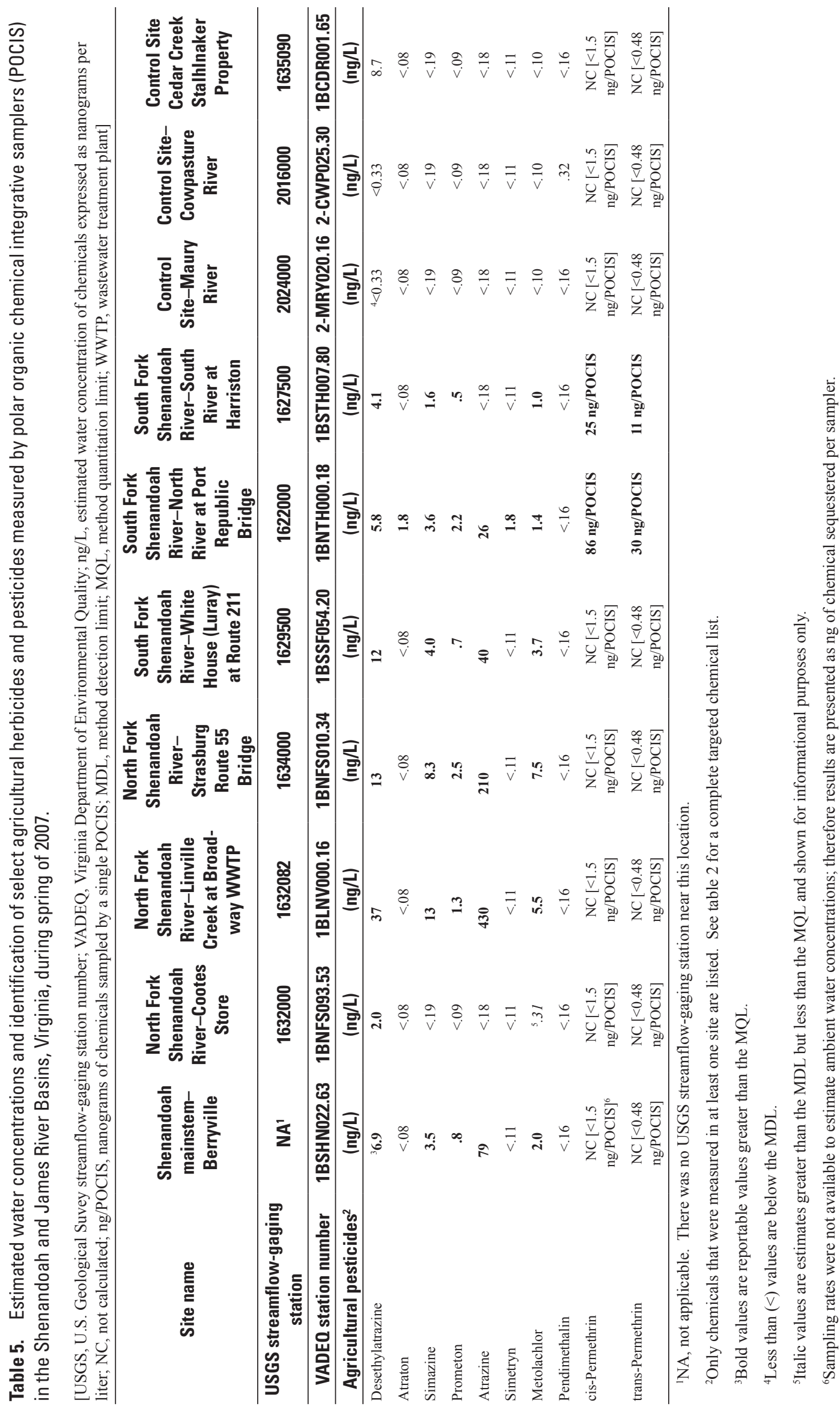




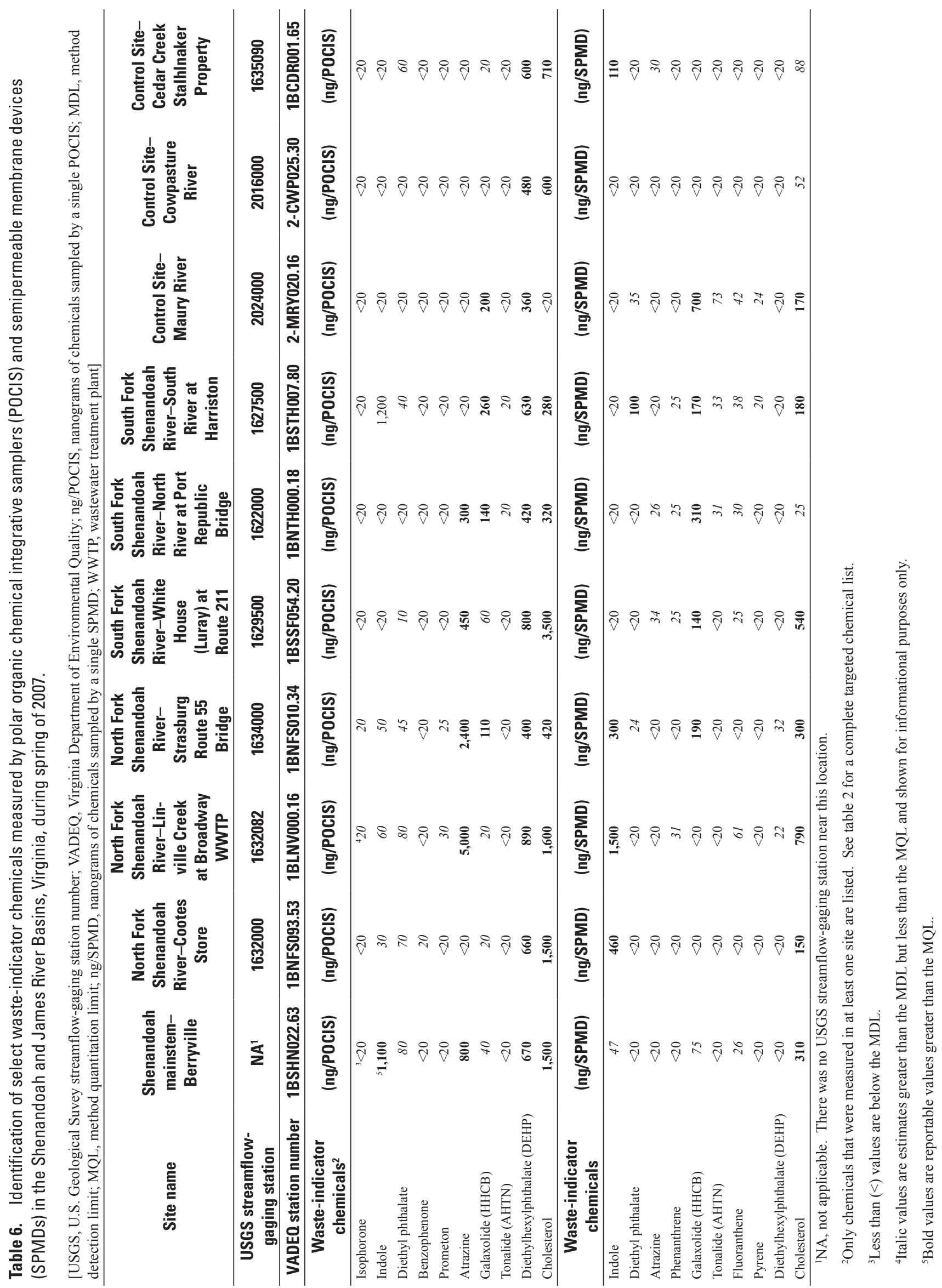




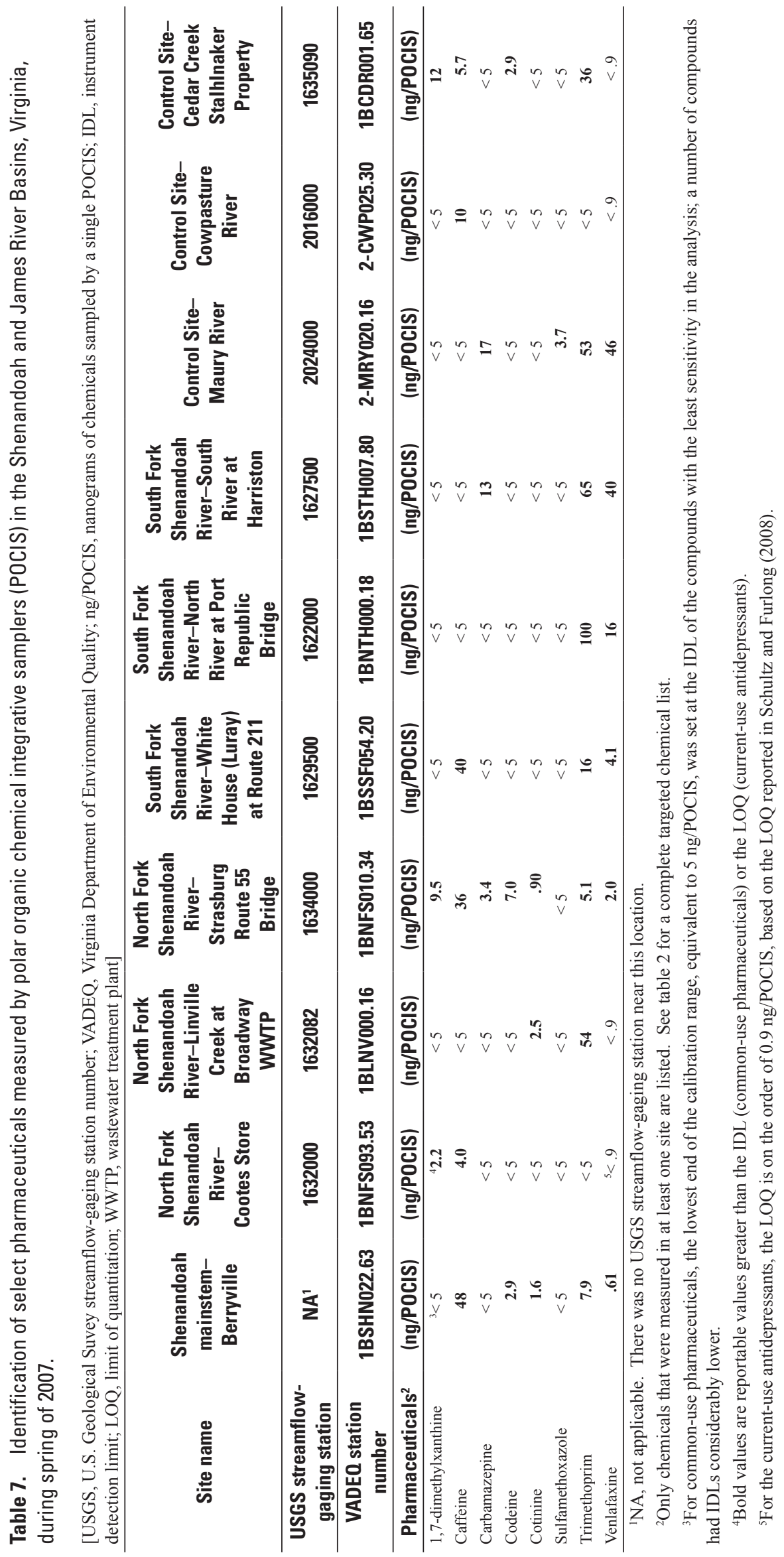




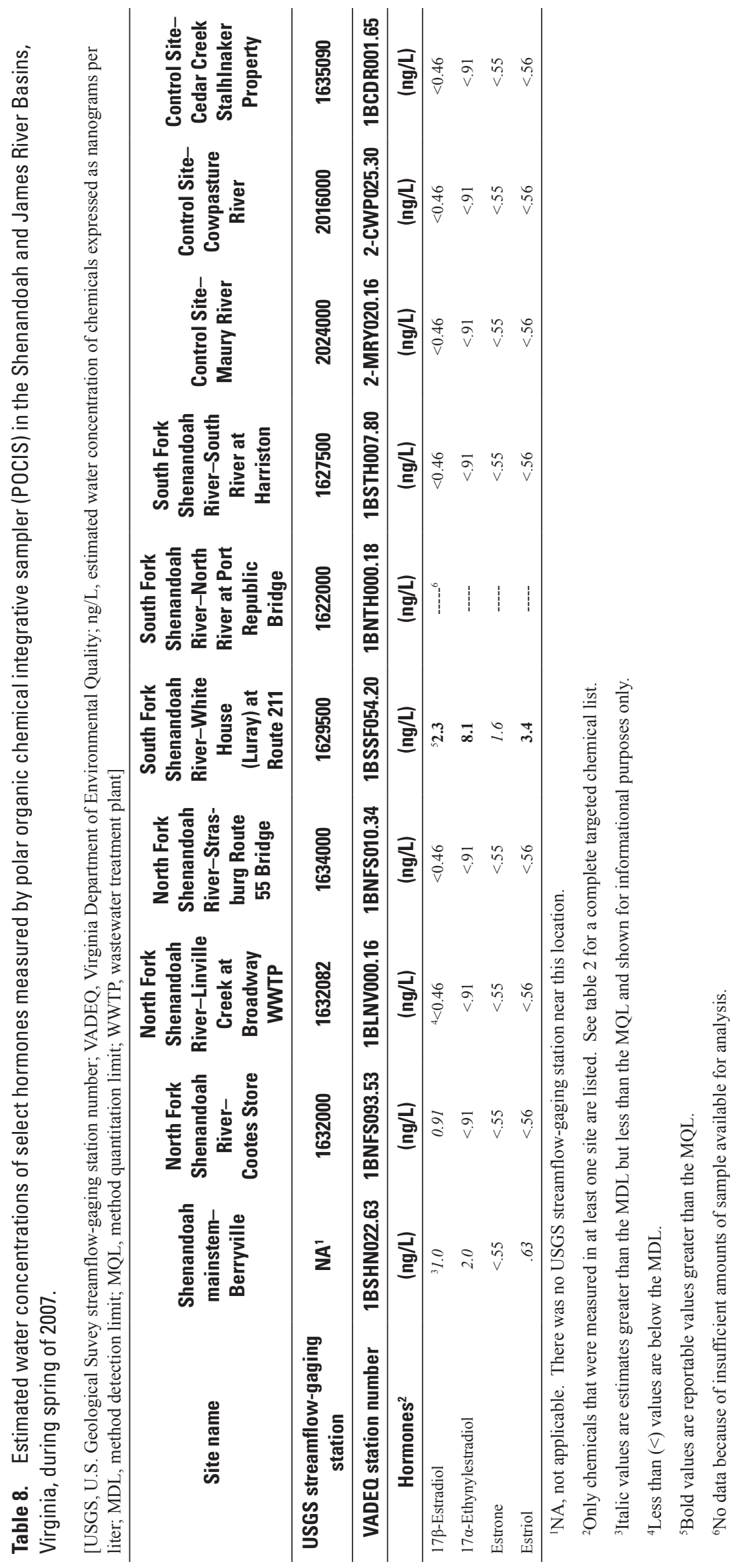




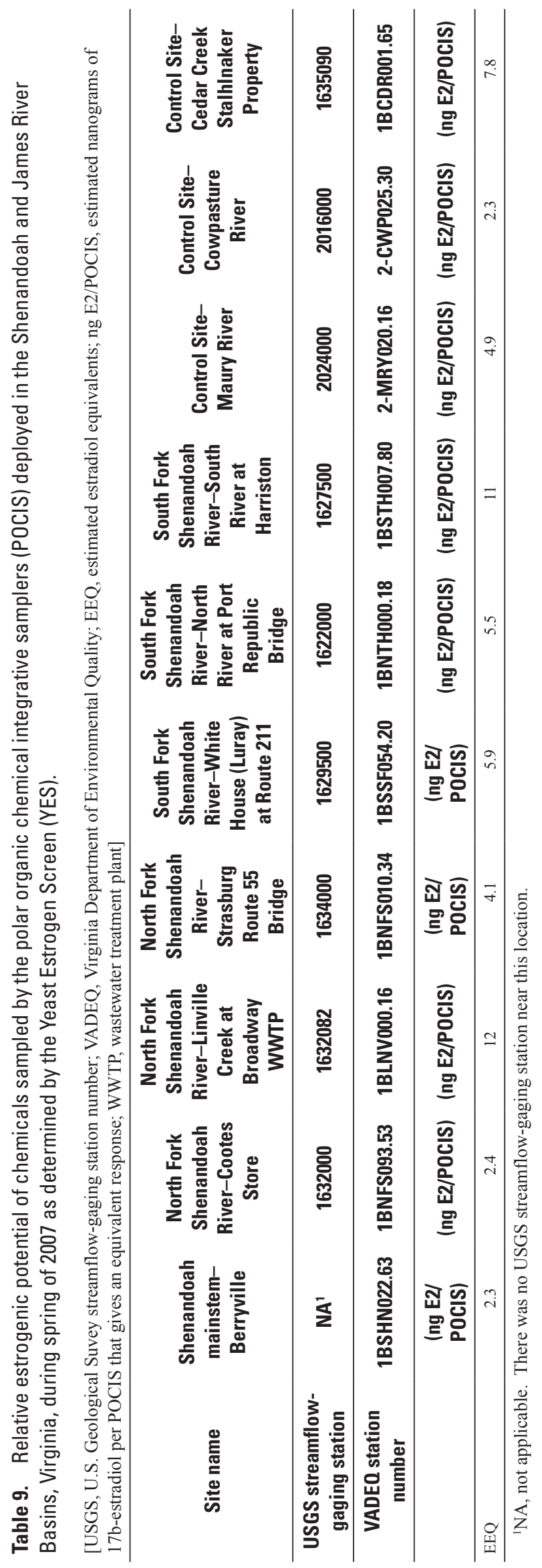


desethylatrazine concentrations at the study sites mirrored each other with maximum concentrations for each found at the North Fork Shenandoah River-Linville Creek at Broadway WWTP site. The broad spectrum insecticide, permethrin (both the cis- and trans- stereoisomers) was detected at the South Fork Shenandoah River-North River at Port Republic and South River at Harriston sites. Prometon, a nonselective herbicide used for weed control along roadways, recreational areas, railroads, industrial, and military areas, was detected at low concentrations at six sites. The identification of atrazine and prometon was confirmed by a secondary analysis of separate POCIS extracts during the waste indicator chemical screen. A direct link between atrazine concentrations and impaired reproductive health of fish has not been identified; however, atrazine remains a suspect because of widespread use and elevated concentrations in the study areas (Bringolf and others, 2004; Chang and others, 2005; Richter and others, 2006).

\section{Waste Indicator Chemicals}

Few waste indicator chemicals were detected, indicating that the sites are minimally effected by effluents from WWTPs or leaking septic systems (table 6). The fragrance compounds galaxolide, tonalide, and indole were detected at low levels at several of the sites, indicating a minor influence from WWTPs. The sites with the highest detected concentrations of the fragrances were the Shenandoah River mainstem at Berryville, North Fork Shenandoah River-Linville Creek at Broadway WWTP site, and the South Fork Shenandoah River-South River at Harriston. Concentrations of diethyl phthalate, diethylhexylphthalate, and cholesterol in the SPMDs were greatly reduced from the original levels as these compounds were largely removed from the samples during the SEC fractionation prior to analysis. The SEC fractionation was a necessary step to remove interferences that impaired the initial analysis of the raw SPMD extracts.

The presence of certain selected chemicals in both the SPMD and POCIS can be used for confirmation purposes; however, lack of the presence of a chemical in one sampler does not indicate an incorrect identification. Many chemicals will be selectively sampled by one device or the other. For example, atrazine was readily sampled by the POCIS; however, only traces of the chemical were found in the SPMDs from the same sites. SPMDs and POCIS often have large differences in the sampling rates of similar chemicals that can result in greatly different amounts of a chemical present in each device. Without knowledge of the sampling rate for the chemical in each sampler, direct comparisons on the basis of the amount of chemical detected in each sampler cannot be made.

\section{Pharmaceuticals}

As observed for the waste indicator chemicals, few pharmaceuticals were detected in the POCIS extracts (table 7). Caffeine, 1,7-dimethylxanthine (a major metabolite of caffeine), cotinine (the metabolite of nicotine), codeine (a narcotic analgesic), and carbamazepine (an anticonvulsant drug) were each detected at several sites. Trimethoprim, an antibiotic commonly prescribed in tandem with sulfamethoxazole, was detected in 8 of 10 sites; however, sulfamethoxazole was detected only at one of these sites. The antidepressant venlafaxine, currently the 13th most prescribed drug in the United States and sold under the tradename Effexor (RxList, 2008), was detected at several sites. The detected amounts of venlafaxine in the POCIS extracts $(<0.9-46 \mathrm{ng} /$ POCIS $)$ are much lower than levels detected in WWTP effluent dominated stream samples $(600-1,000 \mathrm{ng} / \mathrm{L})$ reported by Schultz and Furlong (2008). Little is known about the long-term chronic effects due to exposure to trace concentrations of pharmaceuticals; however, effects are expected to occur as the pharmaceuticals are designed to elicit a biological response (Daughton and Ternes, 1999).

\section{Hormones}

Four steroidal hormones were selected for this study including the natural hormone $17 \beta$-estradiol, the synthetic hormone $17 \alpha$-ethynylestradiol (the main ingredient in oral contraceptives), and the $17 \beta$-estradiol metabolites, estriol and estrone. The hormones were detected at three sites with measurable concentrations at the South Fork Shenandoah River Route 211 site. The synthetic hormone $17 \alpha$-ethynylestradiol had a maximum concentration of $8.1 \mathrm{ng} / \mathrm{L}$ at this site that is important as concentrations as low as $1 \mathrm{ng} / \mathrm{L}$ have been shown to induce intersex in fishes (Länge and others, 2001). Immature rainbow trout have been shown to increase vitellogenin synthesis upon exposure to $17 \alpha$-ethynylestradiol concentrations of $0.1 \mathrm{ng} / \mathrm{L}$ (Purdom and others, 1994). Chronic exposure of fathead minnows (Pimephales promelas) to $17 \alpha$-ethynylestradiol at concentrations of 5-6 ng/L resulted in feminization of males, altered reproduction in females, and near extinction of the species from an experimental test lake in Canada over a seven-year study (Kidd and others, 2007). Routledge and others (1998) indicated that $17 \alpha$-ethynylestradiol could produce an estrogenic response at concentrations 10 -fold lower than other natural steroids. Denny and others (2005) indicated that $17 \alpha$-ethynylestradiol has a higher affinity for the fish estrogen receptor than natural estrogens and presumably a greater biological potency. 


\section{Yeast Estrogen Screen (YES Assay)}

There was measurable estrogenicity in each of the site samples (table 9), although at levels lower than what has been reported in samples from areas heavily effected by WWTP effluent (Vermeirssen and others, 2005). The EEQs estimated in this study were similar to other studies where the surrounding land use was primarily agricultural (Alvarez and others, 2008b; Matthiessen and others, 2006). There were no field blanks used in this study that could be used to determine any potential estrogenicity from the sampler matrix or field contamination. However, no estrogenic response was observed from a laboratory matrix blank, indicating that the sample processing steps and likely the original sample matrix did not contribute to the total measured estrogenicity. The presence of natural and synthetic hormones at some of the sites (table 8 ) would have contributed to some of the measured estrogenicity in the samples; however, the elevated EEQs at the North Fork Shenandoah River-Linville Creek at Broadway WWTP site and South Fork Shenandoah River-South River at Harriston, neither of which had any measurable hormones, indicate that one or more chemicals capable of mimicking the estrogen mode of action were present. The definitive identification of these chemicals was beyond the scope of this study. Because the estrogenicity was found in the POCIS extracts, it is likely the chemical or chemicals responsible for promoting the estrogenic response are more water soluble and less likely to bioaccumulate in fish and other aquatic organisms. Nevertheless, polar chemicals are suspected to have adverse effects on aquatic organisms, even though these chemicals may not bioaccumulate, because of the constant input into the basin (Daughton and Ternes, 1999). However, since extracts from SPMDs were not tested using the YES assay, it cannot be determined how much of the potential estrogenicity from chemicals at the sites was because of hydrophobic chemicals. A definitive study into the identity of the estrogenic chemicals was beyond the scope of this study.

\section{Acknowledgements}

The authors graciously thank the U.S. Environmental Protection Agency and the Virginia Poultry Foundation, for providing funding for this work. We also thank Donald Kain, Ted Turner, and other colleagues with the Virginia Department of Environmental Quality for their efforts in the planning, logistics, and field work part of the project.

\section{References Cited}

Alvarez, D.A., Petty, J.D., Huckins, J.N, Jones-Lepp, T.L., Getting, D.T., Goddard, J.P., and Manahan, S.E., 2004, Development of a passive, in situ, integrative sampler for hydrophilic organic contaminants in aquatic environments: Environmental Toxicology and Chemistry, v. 23, p. 1,640-1,648.

Alvarez, D.A., Huckins, J.N., Petty, J.D., Jones-Lepp, T.L., Stuer-Lauridsen, F., Getting, D.T., Goddard, J.P., and Gravell, A., 2007, Tool for monitoring hydrophilic contaminants in water: polar organic chemical integrative sampler (POCIS) in Greenwood, R., Mills, G., Vrana, B., eds., Passive Sampling Techniques: Comprehensive Analytical Chemistry, v. 48, Elsevier, p. 171-197.

Alvarez, D., Cranor, W., Perkins, S., Schroeder, V., Werner, S., Furlong, E., and Holmes, J., 2008a, Investigation of organic chemicals potentially responsible for mortality and intersex in fish of the North Fork of the Shenandoah River, Virginia during spring of 2007: U.S. Geological Survey Open-File Report 2008-1093, 16 p.

Alvarez D.A., Cranor W.L., Perkins S.D., Clark R.C., and Smith S.B., 2008b, Chemical and toxicological assessment of organic contaminants in surface water using passive samplers: Journal of Environmental Quality, v. 37, p. 1,024-1,033.

Blazer, V.S., Iwanowicz, L.R., Iwanowicz, D.D., Smith, D.R., Young, J.A., Hedrick, J.D., Foster, S.W., and Reeser, S.J., 2007, Intersex (testicular oocytes) in smallmouth bass from the Potomac River and selected nearby drainages: Journal of Aquatic Animal Health, v. 19, p. 242-253.

Bringolf, R.B., Belden, J.B., and Summerfelt, R.C., 2004, Effects of atrazine on fathead minnow in a short-term reproduction assay: Environmental Toxicology and Chemistry, v. 23 , p. 1,019-1,025.

Cahill, J.D., Furlong, E.T., Burkhardt, M.R., Kolpin, D.W., and Anderson, L.G., 2004, Determination of pharmaceutical compounds in surface- and ground-water samples by solidphase extraction and high-performance liquid chromatography/electrospray ionization mass spectrometry: Journal of Chromatography A, v. 1,041, p. 171-180.

Carr, R.L., Ho, L.L., and Chambers, J.E., 1997, Selective toxicity of chlorpyrifos to several species of fish during an environmental exposure: biochemical mechanisms: Environmental Toxicology and Chemisty, v. 16, p. 2,369-2,374. 
Chang, L.W., Toth, G.P., Gordon, D.A., Graham, D.W., Meier, J.R., Knapp, C.W., deNoyelles, F.J., Campbell, S., and Lattier, D.L., 2005, Responses of molecular indicators of exposure in mesocosms: common carp (Cyprinus carpio) exposed to the herbicides alachlor and atrazine: Environmental Toxicology and Chemistry, v. 24, p. 190-197.

Daughton, C.G., and Ternes, T.A., 1999, Pharmaceuticals and personal care products in the environment: agents of subtle change?: Environmental Health Perspectives, v. 107, p. 907-944.

DeGraeve, G.M., Elder, R.G., Woods, D.C., and Bergman, H.L., 1982, Effects of naphthalene and benzene on fathead minnows and rainbow trout: Archives of Environmental Contamination and Toxicology, v. 11, p. 487-490.

Denny, J.S., Tapper, M.A., Schmieder, P.K., Hornung, M.W., Jensen, K.M., Ankley, G.T., and Henry, T.R., 2005, Comparison of relative binding affinities of endocrine active compounds to fathead minnow and rainbow trout estrogen receptors: Environmental Toxicology and Chemistry, v. 24, p. 2,948-2,953.

Gonzalez, J.M., Cabanas, J.M., Martinez, M., and Muñoz, J., 1987, Alterations in acetylcholinesterase activity in plasma and synaptosomal fractions from C.N.S. of rats acutely intoxicated with Lindane. Effect on Succinylcholine: Bulletin of Environmental Contamination and Toxicology, v. 39, p. 647-655.

Hanke, W., Gluth, G., Blubet, H., and Muller, R., 1983, Physiological changes in carps induced by pollution: Ecotoxicology and Environmental Safety, v. 7, p. 229-241.

Huckins, J.N., Petty, J.D., and Booij, K., 2006, Monitors of organic chemicals in the environment-semipermeable membrane devices: Springer, New York.

Joy, R.M., 1982, Mode of action of lindane, dieldrin and related insecticides in the central nervous system: Neurobehavioral Toxicology and Teratology, v. 4, p. 813-823.

Keith L.H., 1991, Environmental Sampling and Analysis: A Practical Guide: CRC, Boca Raton, p. 101-113.

Kidd, K.A., Blanchfield, P.J., Mills, K.H., Palace, V.P., Evans, R.E., Lazorchak, J.M., and Flick, R.W., 2007, Collapse of a fish population after exposure to a synthetic estrogen: Proceedings of the National Academy of Sciences, v. 104, p. 8,897-8,901.

Kolpin, D.W., Furlong, E.T., Meyer, M.T., Thurman, E.M., Zaugg, S.D., Barber, L.B., and Buxton, H.T., 2002, Pharmaceuticals, hormones, and other organic wastewater contaminants in U.S. streams, 1999-2000: a national reconnaissance: Environmental Science and Technology, v. 36, p. 1,202-1,211.
Länge, R., Hutchinson, T.H., Croudace, C.P., Siegmund, F., Schweinfurth, H., Hampe, P., Panter, G.H., and Sumptor, J.P., 2001, Effects of the synthetic estrogen $17 \alpha-$ ethynylestradiol on the life-cycle of the fathead minnow (Pimephales promelas): Environmental Toxicology and Chemistry, v. 20, p. 1,216-1,227.

Lebo, J.A., Almeida, F.V., Cranor, W.L., Petty, J.D., Huckins, J.N., Rastall, A.C., Alvarez, D.A., Mogensen, B.B., and Johnson, B.T., 2004, Purification of triolein for use in semipermeable membrane devices (SPMDs): Chemosphere, v. 54 , p. $1,217-1,224$.

Matthiessen, P., and Roberts, R.J., 1982, Histopathological changes in the liver and brain of fish exposed to endosulfan insecticide during tsetse fly control operations in Botswana: Journal of Fish Diseases, v. 5, p. 153-159.

Matthiessen, P., Arnold, D., Johnson, A.C., Pepper, T.J., Pottinger, T.G., and Pulman, K.G.T., 2006, Contamination of headwater streams in the United Kingdom by oestrogenic hormones from livestock farms: Science of the Total Environment, v. 367, p. 616-630.

Petty, J.D., Orazio, C.E., Huckins, J.N., Gale, R.W., Lebo, J.A., Meadows, J.C., Echols, K.R., and Cranor, W.L., 2000, Considerations involved with the use of semipermeable membrane devices for monitoring environmental contaminants: Journal of Chromatography A, v. 879, p. 83-95.

Purdom, C.E., Hardiman, P.A., Bye, V.J., Eno, N.C., Tyler, C.R., and Sumpter, J.P., 1994, Estrogenic effects of effluents from sewage treatment works: Chemical Ecology, v. 8, p. $275-285$.

Rastall, A.C., Neziri, A., Vukonvic, Z., Jung, C., Mijovic, S., Hollert, H., Nikcevic, S., and Erdinger, L., 2004, The identification of readily bioavailable pollutants in Lake Shkodra/ Skadar using semipermeable membrane devices (SPMDs), bioassays and chemical analysis: Environmental Science and Pollution Research, v. 11, p. 240-253.

Richter, C.A., Pappoulias, D.M., Whyte, J.J., Villeneuve, D.L., Ankley, G.T., and Tillitt, D.E., 2006, Atrazine effects on biomarker of reproductive function in fathead minnow (Pimephales promelas) and Japanese medaka (Oryzias latipes): Abstract book from the 27th annual meeting of SETAC North America, Montreal, Quebec, Canada, November 5-9, 2006, p. 167

Routledge, E.J., Sheahan, D., Desbrow, C., Brighty, G.C., Waldock, M., and Sumpter, J.P., 1998, Identification of estrogenic chemicals in STW effluent. 2. in vivo responses in trout and roach: Environmental Science and Technology, v. 32 , p. $1,559-1,565$. 
Routledge, E.J., and Sumpter, J. P., 1996, Estrogenic activity of surfactants and some of their degradation products assessed using a recombinant yeast screen: Environmental Toxicology and Chemistry, v. 15, p. 241-248.

RxList.com, accessed on January 27, 2008, at http://www. Exlist.com

Schultz, M.M. and Furlong, E.T., 2008, Trace analysis of antidepressant pharmaceuticals and their select degradates in aquatic matrixes by LC/ESI/MS/MS: Analytical Chemistry, v. 80 , p. $1,756-1,762$.
Tran, A.T., Hyne, R.V., and Doble, P., 2007, Determination of commonly used polar herbicides in agricultural drainage water in Australia by HPLC: Chemosphere, v. 67, p. 944-953.

Tripathi, G., and Verma, P., 2004, Endosulfan-mediated biochemical changes in the freshwater fish Clarias batrachus: Biomedical and Environmental Sciences, v. 17, p. 47-56.

Vermeirssen, E.L.M., Körner, O., Schönenberger, R., Suter, M.J.F., and Burkhardt-Holm, P., 2005, Characterization of environmental estrogens in river water using a three pronged approach: active and passive water sampling and the analysis of accumulated estrogens in the bile of caged fish: Environmental Science and Technology, v. 39, p. $8,191-8,198$ 
Publishing support provided by:

Rolla Publishing Service Center

For more information concerning this publication, contact:

Director, USGS Columbia Environmental Research Center 4200 New Haven Road

Columbia, MO 65201

(573) 875-5399

Or visit the Columbia Environmental Research Center Web site at: http://www.cerc.usgs.gov 



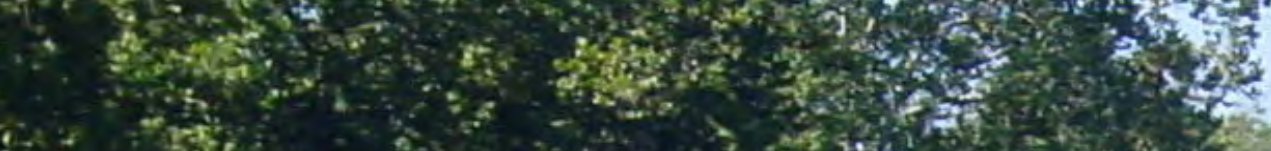

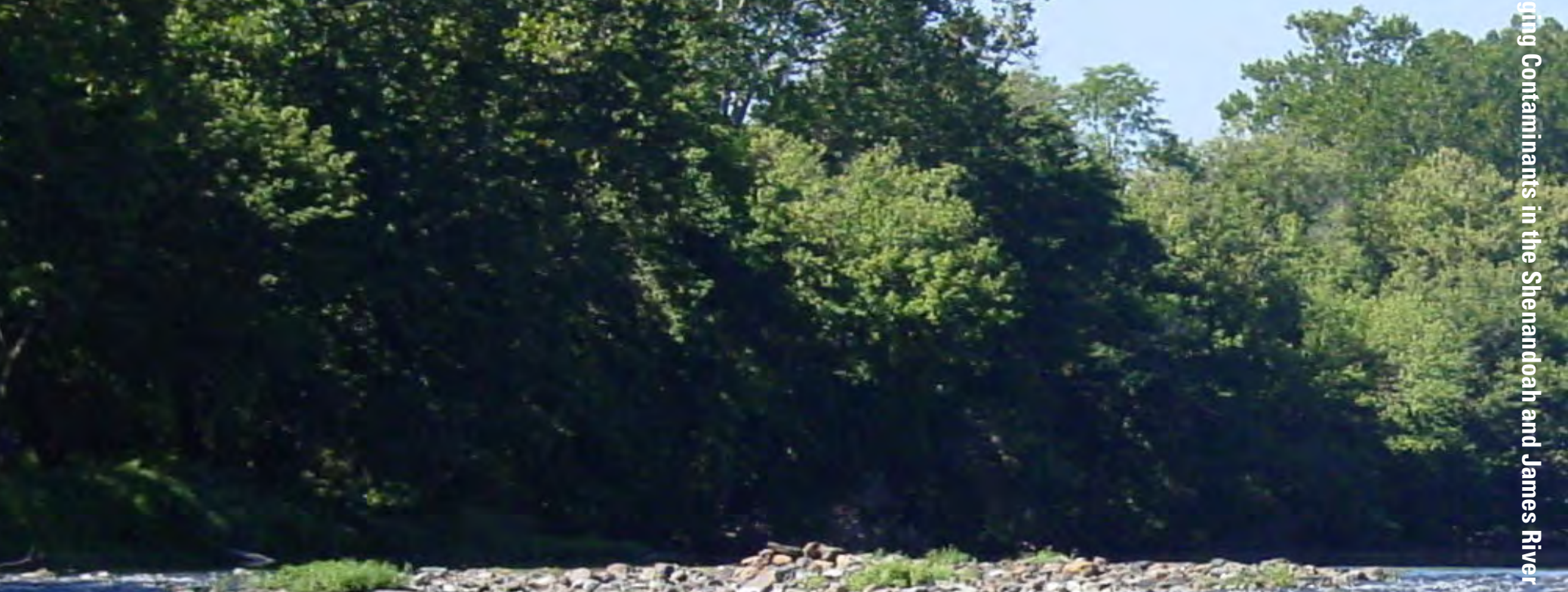

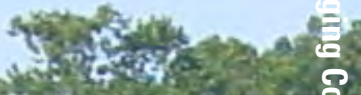

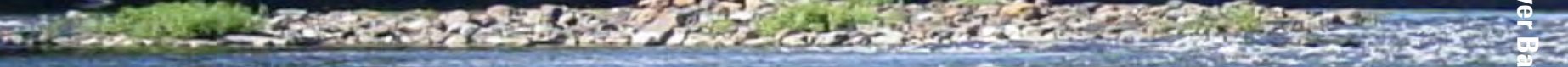

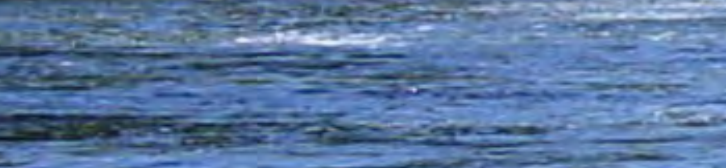

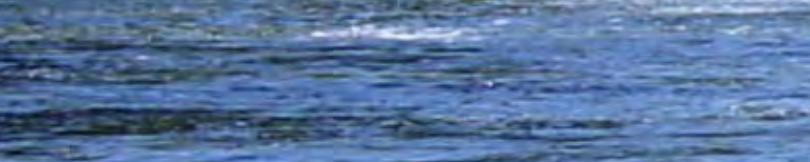

T:-

89

슬

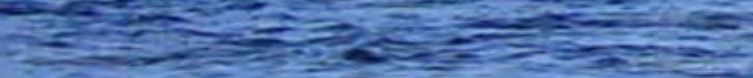

aste 